\title{
Embezzlement scandal rocks Korean universities
}

South Korean universities are to face increased scrutiny after two professors at Seoul National University (SNU) were charged in July with embezzling research funds.

A growing awareness of abuse of research money has spurred a nationwide investigation. Alleged abuses include organizing meetings and entertaining laboratory members with funds that were allocated for different purposes, such as grants for postdocs and other staff.

"Often it's mismanagement rather than embezzlement," says Chan-Mo Park, a digitalimage processing specialist and president of Pohang University of Science and Technology on the east coast.

But in the case of Byung-Hwan Oh, a professor of civil engineering at SNU, the money reportedly found its way into his bank account. Oh, who earlier this year won the American Concrete Institute's Wason Medal for Materials Research, has been charged with misappropriating about 1.6 billion won (US\$1.6 million) in research funds.

The charges say that Oh bought research equipment from companies that did not exist and fabricated receipts. Earlier in July, Youngman Cho, a mechanical engineering professor

\section{IMAGE \\ UNAVAILABLE FOR COPYRIGHT REASONS}

Hustle and bustle: will further grant abuse be uncovered in South Korea's scientists?

at SNU, was detained for the misappropriation of 190 million won.

The cases were a shock to "us and to all the citizens", says Myoung-Mo Kim, chair of SNU's civil-engineering department. The cases have led to the resignation of the dean of SNU's college of engineering.

The state prosecutor's office reportedly has evidence against eight more SNU researchers, as well as material on scientists at five other universities and one national research institute.

Park says the main problem is that SNU and many other Korean universities have no central purchasing office - professors buy their own equipment and research materials. "It's a loophole for unethical people," agrees SunYoung Kim, a molecular biologist at SNU.

He adds that in South Korea big grant winners get no additional salary for their success, and some feel entitled to skim a bit off the top as a reward.

SNU is now trying to establish a central purchasing system, although some of the university's scientists suspect that it might not be able to afford the major investment in staff that would be needed. But there has to be a change of policy, says Myoung-Mo Kim.

Meanwhile, other universities await a visit from the prosecutor's office. Founded 19 years ago, Pohang University of Science and Technology has had a centralized purchasing system from the beginning, says Park. Nevertheless, he is taking measures to boost morale so that researchers do not feel like cheating.

And he is looking into the university's rules and regulations. "There still could be loopholes. If so, we must close them," he says. David Cyranoski

\section{Kansas to rule on copyright for lecture notes}

Should all the writings of faculty scientists automatically belong to their university? The point is being tested in the Kansas Supreme Court, which may rule that all written works produced by faculty members - including lecture notes, books, curricula, websites and articles - are the property of universities by default.

The case began in 1998, when the Kansas Board of Regents, which oversees higher education in the state, produced an intellectual-property policy without consulting faculty members at Kansas's Pittsburg State University. Concerned that researchers could miss out on profits from patents on their inventions, the faculty's union filed a complaint.

When the case arrived at the Topekabased Court of Appeals in 2004, the complaint was rebuffed. The judge cited the 'work-for-hire' rule in federal copyright law. Under this principle, which holds in many other countries, employees surrender all rights to their employers.
Although work produced by academic researchers is strictly part of their job, it is uncertain whether work-for-hire applies to them, and most universities allow copyright to rest with their employees. "The law at the federal level is not clear at all," says Polk Wagner, a specialist on intellectual-property law at the University of Pennsylvania in Philadelphia.

It makes sense for employers at software companies or advertising agencies to own the written material produced by their employees, but extending that principle to academia spells disaster, according to Ann Springer, associate counsel at the Washington-based American Association of University Professors.

The association filed voluntary testimony with the Kansas Supreme Court, stating that applying the work-for-hire rule to faculty members "would wreak havoc with settled academic practices". It added: "Academic freedom requires that faculty be free to produce work reflecting their own views and theories - not those of the university's administration."

After all, says Springer, if a university owns the copyright on a contentious work, it could alter or suppress it. "Scholarly work has to be under the control of the faculty, or it has no value," she says.

However, David Schauner, general counsel for the Topeka-based Kansas National Education Association, which runs the Pittsburg union, says he does not care whether the faculty members are treated as work-for-hire or not. "I think we probably are work-for-hire employees, but that doesn't mean the university can't pay to incentivize my work," he says. "I want a share - this is a capitalist society after all."

Most observers expect the Kansas Supreme Court to overturn the lower court's decision when it rules on 8 September. But if it upholds the work-for-hire ruling, it could influence future cases in other states.

Emma Marris 